\title{
Image monitoring on the behavior study of three genetic groups of confined goats
}

\section{Claudete Maria da Silva ${ }^{1}$, Dermeval Araújo Furtado ${ }^{2}$, Ariosvaldo Nunes de Medeiros ${ }^{3}$, Edilson Paes Saraiva ${ }^{3}$, Walter Esfrain Pereira ${ }^{4}$, Mércia Cardoso da Costa Guimarães ${ }^{5}$}

\author{
${ }^{1}$ Doutoranda em Zootecnia, Universidade Federal da Paraíba, Areia, PB, Brasil. \\ ${ }^{2}$ Departamento de Engenharia Agrícola, Universidade Federal de Campina Grande, Campina Grande, PB, Brasil. \\ ${ }^{3}$ Departamento de Zootecnia, Universidade Federal da Paraíba, Areia, PB, Brasil. \\ ${ }^{4}$ Departamento de Ciências Fundamentais e Sociais, Universidade Federal da Paraíba, Areia, PB, Brasil. \\ ${ }^{5}$ Departamento de Zootecnia, Instituto Federal de Pernambuco, Barreiros, PE, Brasil.
}

\begin{abstract}
The objective of this study was to analyze the behavior of three genetic groups of confined goats by image monitoring using nine unneutered goats of the Azul, Graúna and Moxotó genotypes. The experimental design was completely randomized, in a $3 \times 3$ factorial arrangement (genetic groups $\times$ periods - morning, afternoon and night), with three replications Animals were monitored by video cameras placed at the ceiling of each stall for 10 days. There were interaction factors in the frequency of behavioral categories: interaction with the trough, self-cleaning, standing bipedally, social interaction, and other activities. Azul, Graúna and Moxotó native goats kept in the same environment under the same system of containment and feeding show different frequencies and durations in their behaviors, which are influenced by the period of the day.
\end{abstract}

Key Words: ethogram, feed intake, rumination, social interaction, water consumption

\section{Introduction}

The goat farming practiced in Northeast Brazil stands out among the livestock activities in the region, mainly for production of foods, such as meat and milk as well as byproducts (skin and hair) manufactured or used in crafts, contributing to the income generation for rural population. Because of their adaptive characteristics to arid and semiarid conditions, native goats can survive and produce in these environments, basically consuming native vegetation that consists of arboreal and shrub species (Araújo et al., 2010; Loiola Filho et al., 2012; Parente et al., 2012).

Azul, Graúna and Moxotó genetic groups are highlighted among the native goat breeds, exploited for their different production purposes: meat, milk and skin. Animals are small-to-medium sized, usually reared in extensive or semi-intensive systems. The Blue genotype is in the approval process as a breed, under the name Serrana Azul. They are animals from the Caatinga of Piauí (Brazil), with bluish or bluish-gray fur, small size, measuring about $60 \mathrm{~cm}$, reaching $43.0 \mathrm{~kg}$ average weight at maturity. The Graúna goat is an endangered group, with few herds; its

Received September 18, 2013 and accepted January 23, 2014.

Corresponding author: claudete_m_silva@hotmail.com

http://dx.doi.org/10.1590/S1516-35982014000600007

Copyright (c) 2014 Sociedade Brasileira de Zootecnia. This is an Open Access article distributed under the terms of the Creative Commons Attribution Non-Commercial License, which permits unrestricted non-commercial use, distribution, and reproduction in any medium, provided the original work is properly cited. main features are the color, fully black, shiny coat, and average weight of $40.0 \mathrm{~kg}$ at maturity. Moxotó has the largest population compared with the other genetic groups; these are small animals, having $62 \mathrm{~cm}$ in high, reaching $50 \mathrm{~kg}$ at maturity, with multiple abilities for meat and skin (Ribeiro et al., 2004).

However, farming these animals exclusively on pasture compromises the supply and quality of the final product due to the presence of long drought periods in this region and reduced forage available in the pastures for feeding animals (Rocha et al., 2009). Confinement or semi-confinement of native goats have been recommended and performed aiming to meet the requirements for maintenance and production of animals besides reducing the mortality of young animals due to nutritional deficiencies and parasitic infestations. It also promotes a regular supply of meat, milk and skin, allowing for faster return on invested capital by the reduced age at slaughter and increased production of better-quality carcasses (Medeiros et al., 2009; Fernandes et al., 2010).

Medeiros (2009) emphasizes the importance of studying the behavior of farm animals, especially in cases of confinement or environments to which they are not adapted, which are useful as an indicator of well-being, allowing the producer to adopt more efficient management systems and obtain better productivity rates when detecting any change in behavior. Moreover, it is used for developing models to support the research and management methods for animals (Carvalho et al., 2007; Barros et al., 2011). 
Among the different methodologies used in the study of animal behavior, image monitoring has gained prominence in recent years, mainly because it provides the researcher with several advantages for being quite efficient and accurate. Using this methodology, the outward behavior of animals is not influenced by the human presence, in addition to facilitating the search for more specific and accurate observations in animal behavior. Such behavior can be analyzed repeatedly when it is necessary to capture images of more relevant conducts (Silva et al., 2006; Barbosa Filho et al., 2007; Cordeiro et al., 2011; Souza et al., 2011). The automatic analysis of digital images from video recordings represents an effective alternative to traditional techniques used in behavior studies (Provolo and Riva, 2009). Moreover, one of the advantages of automated monitoring systems is that they can collect data continuously, not disturbing the animals, and are subject to neither (inter)-observer reliability nor other sources of observer bias (Frost et al., 1997).

Many studies on the behavior of production animals using video images (mainly cattle, birds and pigs) are found in the national or international literature (Provolo and Riva, 2009; Porto et al., 2011; Souza et al., 2011; Nääs et al., 2012; Costa et al., 2013), but not for Brazilian native goats, which reinforces the need for studies using this approach on these animals. In this sense, considering the lack of studies on the behavior of confined native goats and the emergence of image monitoring as an important tool to assess animal behavior, this study aimed at evaluating the performance of Azul, Graúna and Moxotó goats kept in confinement by image monitoring.

\section{Material and Methods}

The experiment was conducted at the Experimental Station of São João do Cariri, Research Unit for Small Ruminants, belonging to the Center for Agricultural Sciences, Universidade Federal da Paraíba (UFPB). The city is located at coordinates $7^{\circ} 23^{\prime} 27^{\prime \prime}$ south latitude and $36^{\circ} 31^{\prime} 58^{\prime \prime}$ west longitude. Mean altitude of 450 to $500 \mathrm{~m}$, $26^{\circ} \mathrm{C}$ mean annual temperature and $65 \%$ relative humidity (Table 1). The climate is a Bsh-type (hot semiarid), according to Köppen's classification. In this experiment we determined the description of mean variables during the morning, afternoon and evening, with the following division times: morning: 6.00 to $12.00 \mathrm{~h}$, afternoon: 12.00 to $18.00 \mathrm{~h}$, and night: 18.00 to $00.00 \mathrm{~h}$.

Nine unneutered goats - Azul, Graúna and Moxotó genotypes -, three of each breed, with average initial weights of $14.8,15.22$ and $15.74 \mathrm{~kg}$, respectively, and average age of 5 months were used in this study. The experiment was conducted from January to April 2009. The animals remained confined for a period of 121 days (21 days for adaptation) in a $2.5-\mathrm{m}$ high earthen-floored open shed facing east-west, with access to shade and sun, ceramic tile roof, divided into individual stalls $(3.75 \mathrm{~m} \times 3.75 \mathrm{~m})$. Goats were fed feed and water ad libitum twice daily, at $7.30 \mathrm{~h}$ and $15.30 \mathrm{~h}$ (Figure 1). The animals received a dose of anthelmintic with enhancement after 21 days, and an organic modifier (vitamin and mineral complex) was also applied.

The goats were fed a diet (Table 2) consisting of forage, buffel grass hay and concentrate based on corn, soybean meal and a mineral supplement, provided as complete mixture formulated according to NRC (1981). The forageto-concentrate ratio was 47:53.

Nine color video cameras (Day Night TecVoz, Sony ${ }^{\odot}$ ) were used to record the animal behaviors. The cameras were installed at the ceiling of each stall in February 2009 because it is the hottest month in the region. All cameras had cables connected to a computer, where images were stored and processed. The images were captured by a capture board and recorded on the computer, then recorded on DVDs for visual analysis. The cameras were on (recording) 24/7 for 10 consecutive days.

A total of 810 hours of video image corresponding to 9 animals in $9 \mathrm{~h} /$ day ( $3 \mathrm{~h}$ morning, $3 \mathrm{~h}$ afternoon and $3 \mathrm{~h}$ night) were watched to study and observe the animal behavior. Times were set between $8.00 \mathrm{~h}$ and $11.00 \mathrm{~h}$ (morning), $13.00 \mathrm{~h}$ and $16.00 \mathrm{~h}$ (afternoon) and $18.00 \mathrm{~h}$ to $21.00 \mathrm{~h}$ (night), defined based on the higher frequency of the behavior categories. Image analysis was carried out visually, and computer programs Windows Media Player and Windows Media Player Classic $\left(\right.$ Microsoft $^{\circ}$, Windows 7 version) were used to play the videos.

As stopwatch to record the frequency and duration in seconds of each behavioral category, we used the program

Table 1 - Mean values of climate variables

\begin{tabular}{lcccccc}
\hline Periods & AT & RH & Ws & BGT & ITH & RHL $\left(\mathrm{W} \mathrm{m} \mathrm{m}^{-2}\right)$ \\
\hline Morning $(6.00$ to $12.00 \mathrm{~h})$ & 26.93 & 55.70 & 1.63 & 77.00 & 74.23 & 526.66 \\
Afternoon $(12.00$ to $18.00 \mathrm{~h})$ & 30.85 & 43.80 & 0.80 & 79.35 & 78.10 & 506.70 \\
Night $(18.00$ to $00.00 \mathrm{~h})$ & 22.33 & 73.73 & 0.96 & 70.36 & 70.46 & 445.30 \\
\hline
\end{tabular}

AT - air temperature $\left({ }^{\circ} \mathrm{C}\right) ; \mathrm{RH}$ - relative humidity $(\%)$; Ws - wind speed $\left(\mathrm{m} \mathrm{s}^{-1}\right)$; BGT - index of globe temperature and humidity; ITH - index of temperature and humidity; $\mathrm{RHL}$ - radiant heat load $\left(\mathrm{W} \mathrm{m}^{-2}\right)$. 


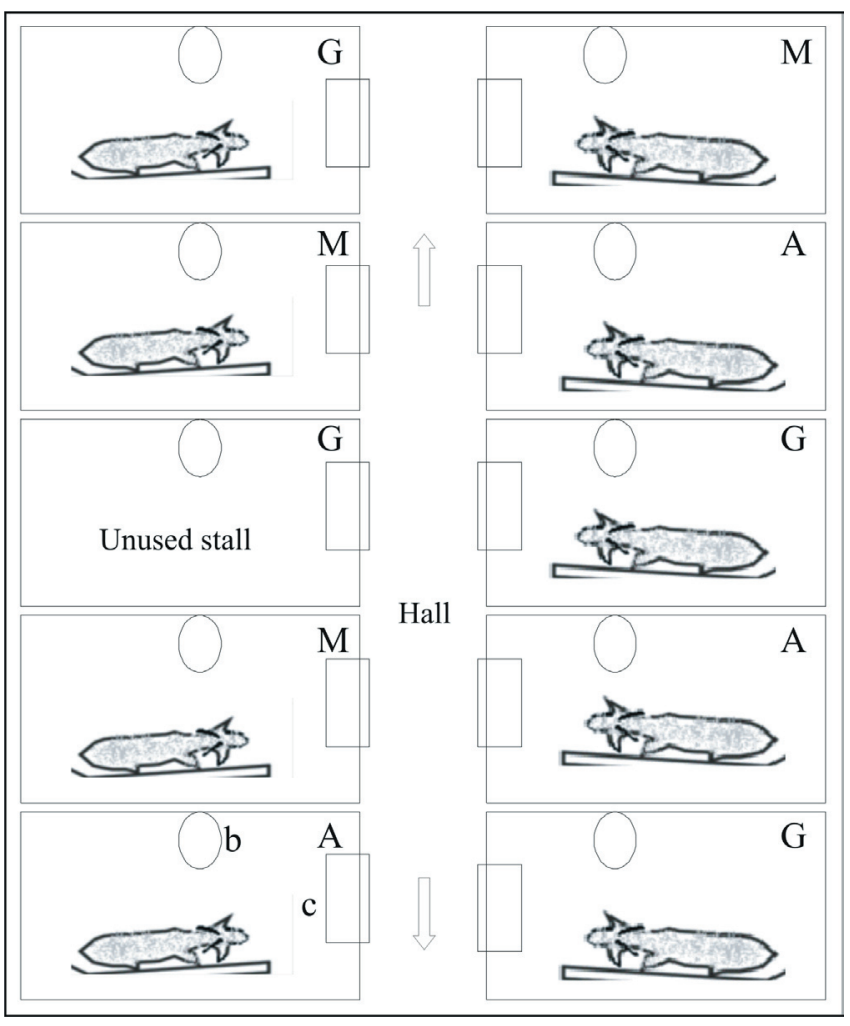

b - drinker; c - trough.

A - Azul; G - Graúna; M- Moxotó.

Figure 1 - Animals disposed in individual stalls in the shed where they were kept confined during the experiment.

EthoLog 2.2 of Ottoni (2000), where behavior categories were inserted; each category was identified by a letter or code for handling during observations and, as the video images were reproduced, the letter for each category was entered on the computer keyboard in accordance with the animal conduct that was processed in the video image; each observation of behaviors was timed for one hour. The following behavioral categories were evaluated:

Consumption/selection of food - goat nods inside the trough and starts eating or selecting the food; it was not possible to see if the goat was eating or selecting food, because animals have the habit of usually selecting the most palatable food and/or of greatest volume before ingesting (Figure 2A); Interaction with the trough - goat approaches the trough and does not eat, supported or placing the forelimbs on the trough, and when facing or very close to it, waits and/or demands food; Water consumption - goat drinks water; Interaction with the drinker - goat visits the drinker and does not drink water, or pushes drinker using the head or horns, licking or biting the drinker; Lying in the shade - animal lies exposed in the shade (Figure 2C); Lying in the sun - animal lies in the sun; Lying at night - goat remains lying down to rest or ruminate; Standing still in the shade - animal remains stationary or idle in the shade; Standing still in the sun - goat stands in the sun; Standing upright at night - goat stands at night; Social interaction - animal influences the behavior of other animals, characterized by social behaviors such as fights, social interactions or other type of behavior; Self-cleaning - goat uses teeth, horns or other body part to scratch and may also lick or rub a part of the body to get rid of ectoparasites; Bipedal posture - goat backed with the forelimbs on the slats that make up the stall and remains in an upright position, holding the hindlimbs in contact with the floor (Figure 2B). Other activities - goat performs a number of activities within the stall, such as walking, running, pushing the gate and putting the head between slats; grazing behavior or looking for food; scraping the stall floor with forelimbs; holding the muzzle in the slats to lick or bite; stretching out; supporting any body part on the stall and alert attitude.

The experimental design was completely randomized, in a $3 \times 3$ factorial arrangement $(3$ genetic groups $\times 3$ periods). The behavioral categories food consumption/ selection; lying in the sun, shade and at night; and standing in the sun, shade and at night were characterized as lasting behaviors (behavioral state), and thus evaluated through their durations, which were subjected to analysis of deviance considering the lognormal distribution, applying the chi-square test and performing the comparison of means by the Tukey test at $5 \%$ probability. The categories water consumption, interaction with the trough and drinkers,

Table 2 - Chemical composition of diet ingredients in \% of dry matter

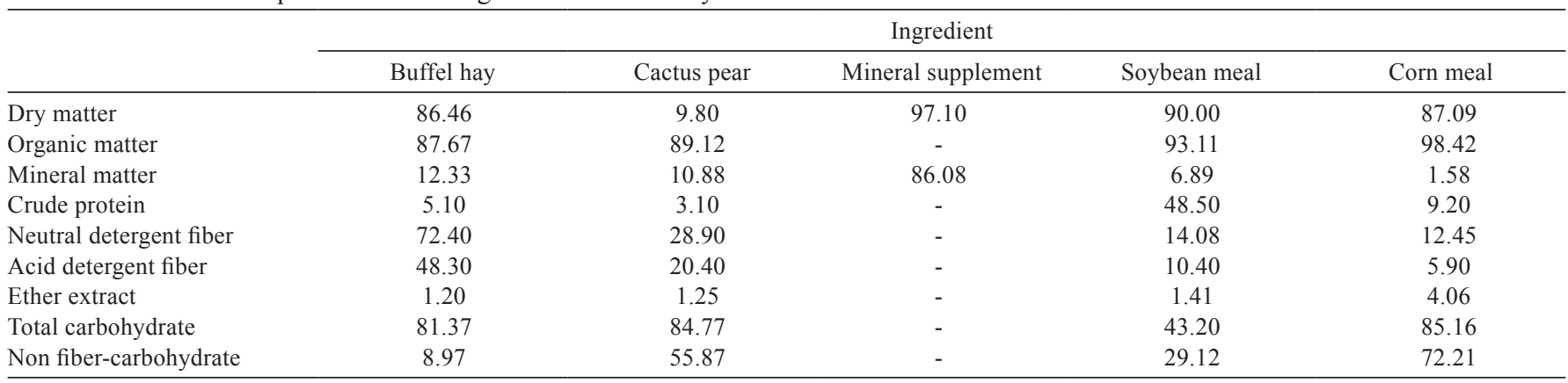



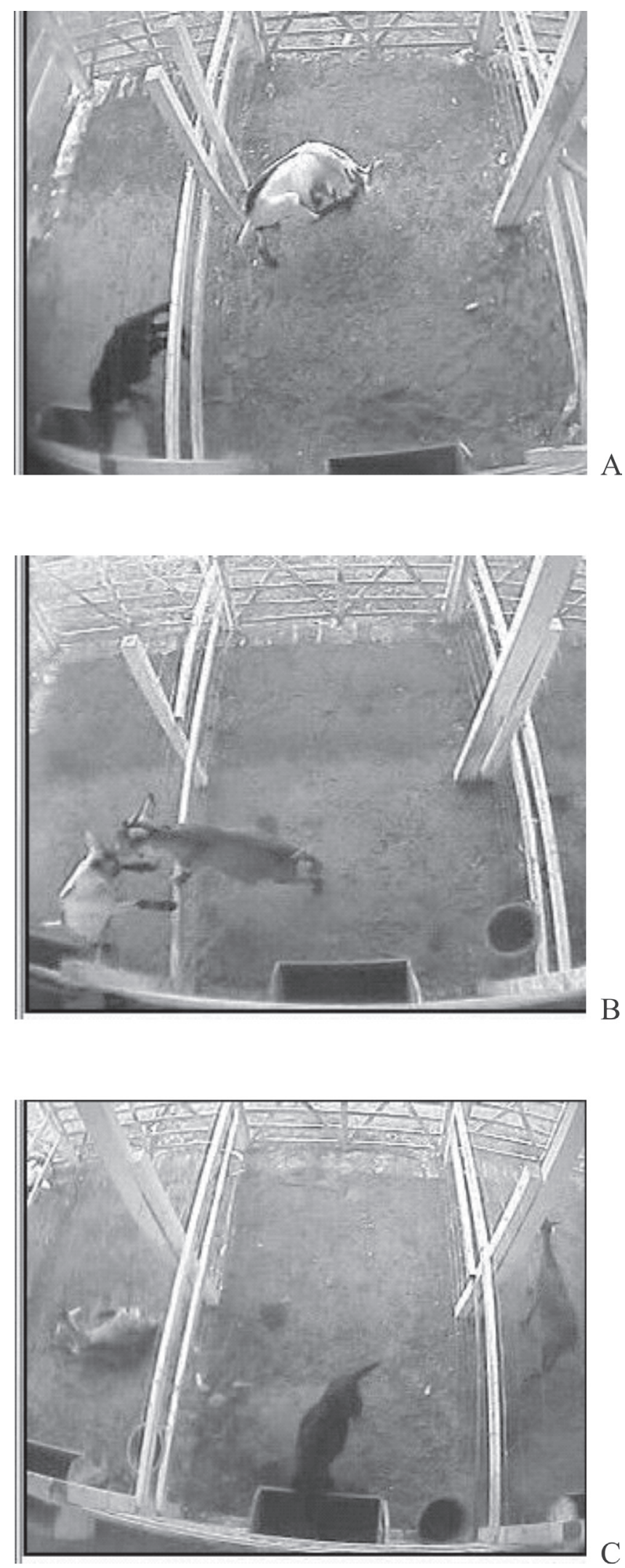

A - Animal eating/selecting food (Graúna - left side); animal grooming (Moxotó - right side).

B - Animals in bipedal position with social behavior characterized as playing (Azul and Moxotó).

$\mathrm{C}$ - Standing animal eating/selecting food (center and right side); animal lying down (left side) (Azul and Graúna).

Figure 2 - Animal behaviors during the experiment. social interaction, self-cleaning, bipedal position and other activities were characterized as short behaviors (behavioral event), having their frequencies recorded and subjected to the Poisson distribution (Pryke, 2009) or Negative Binomial based on the AIC (Akaike Information Criterion), with comparison of means by the Tukey test at $5 \%$ probability.

\section{Results}

With regard to the average duration, in minutes, of food consumption/selection by genetic group (Table 3), no significant difference $(\mathrm{P}>0.05)$ was verified among the goats in the morning, with difference in the afternoon and overnight. In the afternoon, the Graúna and Moxotó animals spent more time selecting and consuming food than Azul, which spent a long time lying down (Table 4), thus reducing trips to the trough. At night, because the Moxotó lie longer, there was less time to consume/select food.

There was no interaction $(\mathrm{P}>0.05)$ between genetic group and the period for the duration of lying and standing still in the sun. The period of the day influenced the duration of categories lying and standing in the shade (Table 4). In the duration of the lying in the shade category (Table 4), the Azul goats remained lying longer than Graúna, and the latter was similar to Moxotó, which spent more time consuming food. Regarding the periods, the animals spent more time lying down in the afternoon.

There were no differences $(\mathrm{P}>0.05)$ in the duration of lying in the sun in the analyzed periods (Table 4), and among animals, Azul spent more time lying than the Graúna and Moxotó groups, demonstrating the ability of first group in heat dissipation. No significant differences were found for the duration of lying at night among genetic groups. The animals remained much of the time in this position, resting and ruminating, due to the consumption of the food from the second supply (15.30 h).

In the categories standing still in the shade and standing in the sun, it was observed that the animals spent more time in these behaviors in the afternoon than in the morning, because they had to wait for the second feed supply, which occurred at $15.30 \mathrm{~h}$. The goats stood in the stall, preferably near the gate, interspersed with walks in the stall. Regarding the category standing still at night, Azul differed from other genetic groups, which did not differ.

The analysis of variance revealed a significant interaction between genetic group and period $(\mathrm{P}<0.05)$ in the frequency of categories: interaction with the trough, self-cleaning, bipedal, social interaction and other activities (Table 5). 
Analyzing the frequency of interaction with the trough between groups, it seems that Graúna and Moxotó interacted more often than Azul in the morning. In the afternoon and evening the Graúna attended the trough more than the other groups, which also showed differences. This difference is linked to the time spent on other behaviors, especially lying. When comparing the two periods, this was more often observed in the morning, with more visits to the trough for consumption or selection of food and interactions with the trough.
In the frequency of self-cleaning category there was no significant difference during the night among the groups; however, the Azul showed lower frequency than the Graúna and Moxotó groups during the morning and afternoon. As for periods, there was higher frequency at night.

In the frequency of the bipedal category (Table 5), groups Azul and Moxotó showed no significant differences in the periods of afternoon and evening; this is certainly related to the higher frequencies of social interactions that

Table 3 - Mean duration of intake/selection of food of genetic groups in the analyzed periods

\begin{tabular}{|c|c|c|c|c|c|}
\hline \multirow{2}{*}{$\begin{array}{l}\text { Food consumption/selection (min.) } \\
\text { Genetic group }\end{array}$} & \multicolumn{3}{|c|}{ Period } & \multirow{2}{*}{ SEM } & \multirow{2}{*}{$\mathrm{P}$-value } \\
\hline & Morning & Afternoon & Night & & \\
\hline Azul & $71.00 \mathrm{a}$ & $18.43 b$ & $18.24 \mathrm{a}$ & 1.05 & 0.1178 \\
\hline Graúna & $95.16 \mathrm{a}$ & $38.58 \mathrm{a}$ & $23.22 \mathrm{a}$ & & \\
\hline Moxotó & $84.44 \mathrm{a}$ & $31.04 \mathrm{a}$ & $7.22 \mathrm{~b}$ & & \\
\hline
\end{tabular}

Means followed by different letters in the same column are significantly different $(\mathrm{P}<0.05)$ by the Tukey test.

SEM - standard error of the mean.

Table 4 - Mean duration, in minutes, of some behavioral categories of genetic groups and periods analyzed

\begin{tabular}{|c|c|c|c|c|c|c|c|c|c|c|}
\hline \multirow{2}{*}{ Categories } & \multicolumn{3}{|c|}{ Genetic group (G) } & \multicolumn{3}{|c|}{ Period (P) } & \multirow{2}{*}{ SEM } & \multicolumn{3}{|c|}{ P-value } \\
\hline & Azul & Graúna & Moxotó & Morning & Afternoon & Night & & G & $\mathrm{P}$ & $\mathrm{G} \times \mathrm{P}$ \\
\hline Lying in the shade & $89.33 \mathrm{a}$ & $56.17 \mathrm{~b}$ & $60.08 \mathrm{ab}$ & $52.49 \mathrm{~b}$ & $84.29 \mathrm{a}$ & - & 1.06 & 0.0448 & $<.0001$ & 0.0106 \\
\hline Lying in the sun & $8.24 a$ & $2.12 \mathrm{ab}$ & $1.00 \mathrm{~b}$ & $4.23 \mathrm{a}$ & $3.08 \mathrm{a}$ & - & 1.08 & 0.0069 & 0.9916 & 0.7819 \\
\hline Lying at night & $127.02 \mathrm{a}$ & $110.07 \mathrm{a}$ & $116.04 \mathrm{a}$ & - & - & 117.44 & 1.15 & 0.2445 & - & - \\
\hline Standing still in the sun & $3.08 \mathrm{a}$ & $3.06 \mathrm{a}$ & $1.22 \mathrm{a}$ & $1.41 \mathrm{~b}$ & $3.03 \mathrm{a}$ & - & 1.08 & 0.1461 & 0.8821 & 0.2298 \\
\hline Standing still in the shade & $8.41 b$ & $19.28 \mathrm{a}$ & $25.26 \mathrm{a}$ & $11.13 b$ & $24.30 \mathrm{a}$ & - & 1.04 & 0.0198 & $<.0001$ & 0.0014 \\
\hline Standing still at night & $6.36 \mathrm{~b}$ & $19.06 \mathrm{a}$ & $20.21 \mathrm{a}$ & - & - & 15.21 & 1.32 & 0.0538 & - & - \\
\hline
\end{tabular}

Means in rows followed by different letters differ by the Tukey test $(\mathrm{P}<0.05)$.

SEM - standard error of the mean.

Table 5 - Mean frequency of some behavioral categories of the three genetic groups in the observed periods

\begin{tabular}{|c|c|c|c|c|c|c|c|}
\hline \multirow[b]{2}{*}{ Genetic groups $(\mathrm{G})$} & \multicolumn{3}{|c|}{ Period (P) } & \multirow[b]{2}{*}{ SEM } & \multicolumn{3}{|c|}{ P-value } \\
\hline & $\begin{array}{c}\text { Morning } \\
(8.00-11.00 \mathrm{~h})\end{array}$ & $\begin{array}{c}\text { Afternoon } \\
(13.00-16.00 \mathrm{~h})\end{array}$ & $\begin{array}{c}\text { Night } \\
(18.00-21.00 \mathrm{~h})\end{array}$ & & G & $\mathrm{P}$ & $\mathrm{G} \times \mathrm{P}$ \\
\hline \multicolumn{8}{|c|}{ Interacting with the trough } \\
\hline Azul & $21.3 \mathrm{Ab}$ & $11.2 \mathrm{Bc}$ & $13.7 \mathrm{Bb}$ & 1.15 & 0.0001 & 0.0001 & $<0.0001$ \\
\hline Graúna & $29.1 \mathrm{Aa}$ & $23.7 \mathrm{Ba}$ & $24.2 \mathrm{Ba}$ & 1.19 & & & \\
\hline Moxotó & $25.7 \mathrm{Aa}$ & $16.3 \mathrm{Bb}$ & $8.4 \mathrm{Cc}$ & 1.14 & & & \\
\hline \multicolumn{8}{|c|}{ Self-cleaning } \\
\hline Azul & $21.5 \mathrm{Bb}$ & $20.1 \mathrm{Bb}$ & $35.6 \mathrm{Aa}$ & 1.05 & $<0.0001$ & $<0.0001$ & $<0.0001$ \\
\hline Graúna & $24.3 \mathrm{Ca}$ & $31.2 \mathrm{Ba}$ & $39.2 \mathrm{Aa}$ & 1.05 & & & \\
\hline Moxotó & $27.3 \mathrm{Ba}$ & $31.3 \mathrm{Ba}$ & 39.9Aa & 1.05 & & & \\
\hline \multicolumn{8}{|c|}{ Bipedal } \\
\hline Azul & $2.1 \mathrm{Bb}$ & $3.4 \mathrm{Aa}$ & $4.2 \mathrm{Aa}$ & 1.17 & $<0.0001$ & $<0.0001$ & $<0.0001$ \\
\hline Graúna & $1.8 \mathrm{Bb}$ & $2.9 \mathrm{Ab}$ & $1.5 \mathrm{Bb}$ & 1.18 & & & \\
\hline Moxotó & $3.7 \mathrm{Aa}$ & 4.9Aa & $3.1 \mathrm{Ba}$ & 1.14 & & & \\
\hline \multicolumn{8}{|c|}{ Social interaction } \\
\hline Azul & $3.6 \mathrm{Ba}$ & $5.5 \mathrm{Aa}$ & $3.6 \mathrm{Ba}$ & 1.15 & $<0.0001$ & $<0.0001$ & 0.0452 \\
\hline Graúna & $1.7 \mathrm{Bb}$ & $3.5 \mathrm{Ab}$ & $1.2 \mathrm{Bb}$ & 1.19 & & & \\
\hline Moxotó & $3.5 \mathrm{Ba}$ & $6.0 \mathrm{Aa}$ & $3.6 \mathrm{Ba}$ & 1.14 & & & \\
\hline \multicolumn{8}{|c|}{ Other activities } \\
\hline Azul & $51.3 \mathrm{Bb}$ & $54.2 \mathrm{Bb}$ & 61.9Aa & 1.07 & $<0.0001$ & $<0.0001$ & $<0.0001$ \\
\hline Graúna & $55.5 \mathrm{Bb}$ & $69.4 \mathrm{Aa}$ & $55.7 \mathrm{Bb}$ & 1.07 & & & \\
\hline Moxotó & $61.9 \mathrm{Ba}$ & $70.6 \mathrm{Aa}$ & $62.7 \mathrm{Ba}$ & 1.06 & & & \\
\hline
\end{tabular}

Means followed by uppercase letters in the row and lowercase letters in column differ statistically by the Tukey test $(\mathrm{P}<0.05)$.

SEM - standard error of the mean. 
have existed, since they always assumed a bipedal posture during fights and/or games when interacting. The Graúna goats had low frequency in bipedal posture compared with the other groups due to the low frequency of social conducts. In periods, the highest frequency of the bipedal posture occurred in the afternoon, recorded in Moxoto goats, which averaged 4.9 times per period.

The frequency of category social interaction was different among groups, where Azul and Moxotó showed no significant differences in the three periods, with higher frequency of social interactions among them than Graúna. Between the periods, social behavior was more frequent in the afternoon for all groups, due to the expectation for the second feed supply, because the highest frequencies of social aggressive conducts and playing among goats were recorded prior to this moment, but the frequency of other activities and bipedal posture also increased.

Regarding the frequency of other activities, groups Graúna and Moxotó showed no significant difference in the afternoon; the lowest value was found for the Azul group. However, no significant differences were found between genetic groups Azul and Moxotó at night. As regards the periods, there was higher frequency in other activities by animals in the afternoon, except for Azul. The increased frequency of other activities in the afternoon was due to the eagerness of animals waiting for the second feeding.

There was no significant interaction $(\mathrm{P}>0.05)$ in the frequency of categories water consumption and interaction with the trough (Table 6). The genetic group Moxoto attended and had less interaction with the trough, which may be related to its smaller size and high adaptability to the Brazilian semiarid conditions. The Graúna group had higher frequency of interactions with the water drinker, which was also associated with food consumption.

As for water consumption per period, the animals reached for the drinker or sought water in the morning (mean 3.5 times), decreasing in the afternoon (mean 1.2 times) and in the evening there was almost no such activity. By the morning this activity was associated with the consumption of food and visits to the trough, which was interspersed with drinking water, whereas in the afternoon, even with the higher temperature (Table 1), animals spent more time lying down and consumed less food. The lower consumption at night was due to the low temperature (Table 1), which is consistent with the homeothermic condition and the reduced food consumption (Table 3).

In category interaction with the trough, the Graúna attended the water drinker more times, and no difference was observed between the morning and afternoon periods. Similar to the frequency of water consumption, at night there was little interaction with the drinker.

\section{Discussion}

Goats are animals adapted to semiarid regions, where they are grown extensively; however, due to the low food supply during the dry season, they may show changes in their behavior. In confinement, the genetic groups showed different behavior at the time of consumption or selection of food in the afternoon and evening periods. The Graúna goats, although having darker hair that may lead to higher internal surface temperature and consequently higher respiration rate than Azul (Leite et al., 2012), spent more time in consuming/selecting food. Longer feed intake and greater weight gain were found in the Graúna goats in another study using the same animals (Leite et al., 2012).

Regarding the duration of category lying, animals remained longer in the afternoon because goats devote more time to rest in this period; and this behavior was also observed by Marques et al. (2006), who, studying the behavior of feedlot crossbred cattle with and without access to shade, verified higher feed intake and upright resting in the morning, with the afternoon being the period in which animals showed the greatest rest activity.

The genetic group Azul spent more time lying in the sun, confirming its greater adaptability. Rocha et al. (2009), working on the climatic adaptability of Azul goats in Mid-North Brazil, concluded that these animals are well adapted to the tropical climate, managing to keep the rectal temperature and respiratory rate low, with good heatdissipation capacity in this region.

Table 6 - Mean frequencies of behavioral categories water consumption and interaction with the drinker of the genetic groups and periods analyzed

\begin{tabular}{|c|c|c|c|c|c|c|c|c|c|c|}
\hline \multirow{2}{*}{ Behavior $^{1}$} & \multicolumn{3}{|c|}{ Genetic group (G) } & \multicolumn{3}{|c|}{ Period (P) } & \multirow{2}{*}{ SEM } & \multicolumn{3}{|c|}{ P-value } \\
\hline & Azul & Graúna & Moxotó & Morning & Afternoon & Night & & $\mathrm{G}$ & $\mathrm{P}$ & $\mathrm{G} \times \mathrm{P}$ \\
\hline Water consumption & $2.5 \mathrm{a}$ & $2.7 \mathrm{a}$ & $1.7 \mathrm{~b}$ & $3.5 \mathrm{a}$ & $1.2 \mathrm{~b}$ & $0.01 \mathrm{c}$ & 1.39 & 0.0230 & $<0.0001$ & 0.2286 \\
\hline Interaction with the drinker & $2.0 \mathrm{~b}$ & $3.1 \mathrm{a}$ & $1.2 \mathrm{c}$ & $3.1 \mathrm{a}$ & $2.7 \mathrm{a}$ & $0.01 \mathrm{c}$ & 1.13 & $<0.0001$ & $<0.0001$ & 0.0640 \\
\hline
\end{tabular}

${ }^{1}$ Occurrences in 3 hours.

Means followed by different letters in the rows are significantly different $(\mathrm{P}<0.05)$ by the Tukey test.

SEM - standard error of the mean. 
As expected, the animals lie longer during the evening, because ruminants perform more rumination in this period of the day (Zanine et al., 2008; Hübner et al., 2008, Marques et al., 2012; Oliveira et al., 2013).

The Azul group, for remaining longer standing and lying in the sun, reduced their self-cleaning conducts. This was probably due to the increase in the temperature on their skin, which reduced the activity of ectoparasites (Santos et al., 2006). In the self-cleaning frequency, there were no differences among groups. Mooring et al. (1998) and Kakuma et al. (2003), studying the effects of castration on the self-cleaning habit of goats, observed that larger episodes occurred in castrated males. At night there was a greater frequency of self-cleaning, probably due to the higher relative humidity (Table 1), which favored the presence or increased activity of parasites (Hutchens et al., 2009), while frequencies were lower in the afternoon and morning due to the insolation and low relative humidity at the stall coupled with increased ventilation (Table 1), resulting in lower activities of external parasites.

The bipedal posture is a characteristic behavior that provides goats with advantages when under grazing conditions; they are also quite agile compared with sheep and cattle (Sanon et al., 2007). Ribeiro (1997) mentions that due to their eating habits and the manner of domestication, goats have a greater preference for tall plants than cattle and sheep. Consequently, once in natural conditions, they are free from being infested by the vast majority of endoparasites, thereby developing less resistance to them, since they are infested in a much less severe way than sheep and cattle, which had to develop resistance to survive. In the studied native goats, the animals were in the bipedal position so as to perform other activities, e.g. interacting socially, observing the arrival or approach of people, biting or licking the wooden column that supports the stall, and standing bipedal without having any other conduct. The bipedal behavior occurred more frequently in the afternoon. Oliveira (2010) noted that the frequency of bipedal posture was concentrated in the afternoon, in the period preceding the feed supply. These results are similar to those found herein: although random, the highest occurrences of bipedal posture were in the afternoon due to the expectation for the second feed supply.

The highest frequency of social interactions was observed in the afternoon, especially with fights or aggressive interactions between animals. Orgeur et al. (1990) reported that in intensive goat-production systems, levels of aggression are higher than those in semi-intensive and extensive systems. This was also verified by Barroso (2000), who reported that the frequency of aggressive interactions were higher among goats kept indoors than those on pastures, probably because of differences in space availability, which was more limited in indoors. The goats of the present study showed high eagerness in the hours that preceded feed delivery, and the proximity between the stalls where they were confined contributed to their aggressive behavior towards each other.

The interactions among these animals are typical signs of communication between them, and almost all social behavior involves some sort of communication that can occur for a variety of modalities; through sounds, but also sight and touch (Gonçalves Neto et al., 2009).

When animals are near others or live in an open habitat they can make use of signals such as the use of horns to establish communication (Weary and Fraser, 2002). In the case of the studied goats, the most used form of communication was the touch, especially with horns, then with the forelimbs and also by touching the neck with their snout. These behaviors were more frequently observed in the afternoon. When wrestling, the horns represent to the goats a source of power and strength, since animals frequently use it when fighting for territory, food, females and control of the flock (Alados, 1984).

The highest frequency of other activities was recorded in the afternoon. Beserra et al. (2007), studying the behavior of goats in confinement, found that the animals spent a greater portion of other activities in the afternoon. These results differ from those found by Pompeu et al. (2009), who found higher percentage of other activities between 17.00 and $23.00 \mathrm{~h}$. In this case we should consider that the animals moved more because they were on pasture looking for food, while those in this study fed at the trough, reducing practices of other activities in the morning.

Visits to the drinker for water intake occurred more frequently in the morning. Ribeiro et al. (2006), studying the feeding behavior of Moxotó and Canindé goats, observed that the demand for water occurred more frequently in the period from 06.00 to $12.00 \mathrm{~h}$, and justify that this was because it was the hottest period of the day and for habit these animals developed most of their activities during the day, while from 18.00 to 06.00 hours on average frequency was 0.39 , similar to the data of this work.

As for water consumption, the animals ingested the water provided in a lower frequency, which can be explained by their more efficient use of the water consumed (NRC, 2007; Araújo et al., 2010). Water intake is related to feed intake because water is required in metabolic processes for nutrient digestion and absorption, which explains the higher frequency of water consumption during the morning, in which increased frequency of food consumption was also 
displayed (Table 2). When in field conditions, animals seek water especially during the hottest hours of the day, and in some cases water is used as a way to dissipate the heat, rather than shaded spaces (Araújo et al., 2010).

\section{Conclusions}

The native goat breeds Blue, Graúna and Moxotó kept in the same environment under the same containment system and food show different frequencies and durations in their behaviors, and these behaviors are influenced by the period of the day. Because of their low frequency in the social interaction category, especially fighting, Graúna goats are less aggressive and spend more time on visits to the trough to consume or select food.

\section{Acknowledgments}

The authors thank Universidade Federal da Paraíba and CNPq.

\section{References}

Alados, C. L. 1984. Etograma de la cabra montés (Capra pyrenaica) y comparación com otras especies. Acta Vertebrata 11:289-309.

Araújo, G. G. L.; Voltolini, T. V.; Chizzotti, M. L.; Turco, S. H. N. and Carvalho, F. F. R. 2010. Water and small ruminant production. Revista Brasileira de Zootecnia 39(supl. especial):326-336.

Barbosa Filho, J. A. D.; Silva, I. J. O.; Silva, M. A. N. and Silva, C. J. M. 2007. Avaliação dos comportamentos de aves poedeiras utilizando seqüência de imagens. Engenharia Agrícola 27:93-99.

Barros, C. S.; Monteiro, A. L. G.; Dittrich, J. R.; Fernandes, M. A. M. and Pinto, S. 2011. Comportamento social de ovinos: apresentação de técnicas. Scientia Agraria Paranaenis 10:5-20.

Barroso, F. G.; Alados, C. L. and Boza, J. 2000. Social hierarchy in the domestic goat: effect on food habits and production. Applied Animal Behavior Science 69:35-53.

Beserra, L. T.; Cândido, M. J. D.; Meneses, A. J. G.; Lima, D. M. and Valente, B. S. M. 2007. Comportamento de caprinos confinados recebendo dietas à base de silagem de capim elefante contendo bagaço de caju desidratado em dois sistemas de arraçoamento. In: Anais da 44a Reunião Anual da Sociedade Brasileira de Zootecnia. Sociedade Brasileira de Zootecnia, Jaboticabal.

Carvalho, G. G. P.; Pires, A. J. V.; Silva, H. G. O.; Veloso, C. M. and Silva, R. R. 2007. Aspectos metodológicos do comportamento ingestivo de cabras lactantes alimentadas com farelo de cacau e torta de dendê. Revista Brasileira de Zootecnia 36:103-110.

Cordeiro, M. B.; Tinôco, I. F. F.; Mesquita Filho, R. M. and Sousa, F. C. 2011. Análise de imagens digitais para avaliação do comportamento de pintainhos de corte. Revista Engenharia Agrícola 31:418-426.

Costa, A. M.; Ismayilova, G.; Borgonovo, F.; Leroy, T.; Berckmans, D. and Guarino, M. 2013. The use of image analysis as a new approach to assess behaviour classification in a pig barn. Acta Veterinaria Brno 82:25-30.

Fernandes, M. A. M.; Monteiro, A. L. G.; Candal Poli, C. H. E.; Barros, C. S.; Almeida, R. and Ribeiro, T. M. D. 2010. Composição tecidual da carcaça e perfil de ácidos graxos da carne de cordeiros terminados a pasto ou em confinamento. Revista Brasileira Zootecnia 39:1600-1609.

Frost, A. R.; Schofield, C. P.; Beaulah, S. A.; Mottram, T. T.; Lines, J.A. and Wathes, C. M. 1997. A review of livestock monitoring and the need for integrated systems. Computers and Electronics Agriculture 17:139-159.

Gonçalves Neto, J.; Teixeira, F. A.; Nascimento, P. V. N. and Marques, J. A. 2009. Comportamento social de ruminantes. Revista Eletrônica Nutritime 6:1039-1055.

Hübner, C. H.; Pires, C. C.; Galvani, D. B.; Carvalho, S.; Jochims, F.; Wommer, T. P. and Gasperin, B. G. 2008. Comportamento ingestivo de ovelhas em lactação alimentadas com dietas contendo diferentes níveis de fibra em detergente neutro. Ciência Rural 38:1078-1084.

Hutchens, T.; Harmon, R. and Andries, K. 2009. High temperatures and heat stress reduces productivity for meat and dairy goats. Goat Producer's Newsletter. Available at: <http://www.uky.edu/Ag/ AnimalSciences/goats/newsletter/Julygoatproducersnewsletter07 09.pdf> Accessed on: Mar. 17, 2014.

Kakuma, Y.; Takeuchi, Y.; Moria, Y. and Hart, B. L. 2003. Hormonal control of grooming behavior in domestic goats. Physiology \& Behavior 78:61-66.

Leite, J. R. S.; Furtado, D. A.; Leal, A. F.; Souza, B. B. and Silva, A. S. 2012. Influência de fatores bioclimáticos nos índices produtivos e fisiológicos de caprinos nativos confinados. Revista Brasileira de Engenharia Agrícola e Ambiental 16:443-448.

Loiola Filho, J. B.; Santos, B. R. C.; Mamera, D. B.; Nogueira, D. M. and Voltolini, T. V. 2012. Consumo de água e desempenho produtivo de caprinos recebendo rações contendo diferentes teores de caroço de algodão em substituição a silagem de maniçoba. Revista Caatinga 25:102-109.

Marques, J. A.; Caldas Neto, S. F.; Groff, A. M.; Simonelli, S. M.; Corasa, J.; Romero, L.; Zawadski, F. and Araújo, P. F. 2006. Comportamento de bovinos mestiços em confinamento com e sem acesso a sombra durante o período de verão. Campo Digital 1:54-59.

Marques, J. A.; Prado, I. N.; Silva, P. A.; Strada, E. S. O.; Santana, A. L. A.; Pinheiro, E. E. G.; Mercês, L. M. and Santos, L. M. 2012. Comportamento ingestivo de diferentes categorias de ovinos Santa Inês em pastejo contínuo em Brachiaria decumbens. Campo Digital 7:37-44.

Medeiros, G. R.; Carvalho, F. F. R.; Batista, A. M. V.; Dutra Júnior, W. M.; Santos, G. R. A. and Andrade, K. B. 2009. Efeitos dos níveis de concentrado sobre características de carcaça de ovinos Morada Nova em confinamento. Revista Brasileira de Zootecnia 38:718-727.

Medeiros, L. F. D. 2009. Bem-estar e produção animal. Universidade Federal Rural do Rio de Janeiro, Seropédica.

Mooring, M. S.; Gavazzi, A. J.; Hart, B. L. 1998. Effects of castration on grooming of goats. Physiology \& Behavior 64:707-713.

Nääs, I. A.; Laganá, M.; Mollo Neto, M.; Canuto, S. and Pereira, D. F. 2012. Image analysis for assessing broiler breeder behavior response to thermal environment. Revista Engenharia Agrícola 32:624-632.

NRC - National Research Council. 1981. Nutrient requirement of domestics animals: nutrient requirement of goats. Washington, D.C.

NRC - National Research Council. 2007. Nutrient requirements of ruminants: sheep, goats, cervids, and new world camelids. National Academy Press, Washington, D.C.

Oliveira, D. 2010. Impacto negativo da restrição alimentar sobre o bem-estar de cabritos alojados em gaiolas metabólicas. Dissertação (M.Sc.). Universidade Estadual Paulista, Jaboticabal.

Oliveira, F. A.; Turco, S. H. N.; Araújo, G. G. L.; Clemente, C. A. A.; Voltolini, T. V. and Garrido, M. S. 2013. Comportamento de ovinos da raça Santa Inês em ambientes com e sem disponibilidade de sombra. Revista Brasileira de Engenharia Agrícola e Ambiental $17: 346-351$ 
Orgeur, P.; Mimouni, P. and Signoret, J. P. 1990. The Influence of rearing conditions on the social relationships of young male goats. Applied Animal Behavior Science 27:105-113.

Ottoni, E. B. 2000. EthoLog 2.2: a tool for the transcription and timing of behavior observation sessions. Behavior Research Methods, Intruments, \& Computers 32:446-449.

Parente, H. N.; Andrade, A. P.; Silva, D. S.; Santos, E. M.; Araujo, K. D. and Parente, M. O. M. 2012. Influência do pastejo e da precipitação sobre a fenologia de quatro espécies em área de caatinga. Revista Árvore 36:411-421.

Pompeu, R. C. F. F.; Rogério, M. C. P.; Cândido, M. J. D.; Neiva, J. N. M.; Guerra, J. L. L. and Gonçalves, J. S. 2009. Comportamento de ovinos em capim-tanzânia sob lotação rotativa com quatro níveis de suplementação concentrada. Revista Brasileira de Zootecnia 38:374-383.

Porto, S. M. C.; Arcidiacono, C.; Guarnera, G. C. and Cascone, G. 2011. Preliminary study for the implementation of an image analysis algorithm to detect dairy cow presence at the feed barrier. Journal of Agricultural Engineering 42:17-23.

Pryke, S. R. 2009. Is red an innate or learned signal of aggression and intimidation? Animal Behaviour 78:393-398.

Provolo, G. and Riva E. 2009. One year study of lying and standing behaviour of dairy cows in a fre-stall barn in Italy. Journal of Agricultural Engineering 40:22-33.

Ribeiro, S. D. A. 1997. Caprinocultura: Criação racional de caprinos. Nobel, São Paulo.

Ribeiro, M. N.; Gomes Filho, M. A.; Bermejo, J. V. D.; Vallejo, M. E. C.; Oliveira, J. C. V.; Cruz, G. R. B.; Rocha, L. L.; Silva, R. C. B.; Menezes, M. P. C.; Ferreira, M. P. B. and Pimenta Filho, E. C. 2004. Conservação de raças caprinas nativas do Brasil: Histórico, situação atual e perspectivas. UFRPE, Imprensa Universitária, Recife.
Ribeiro, V. L.; Batista, A. M. V.; Carvalho, F. F. R.; Mattos, C. W. and Alves, K. S. 2006. Comportamento ingestivo de caprinos Moxotó e Canindé submetidos a alimentação a vontade e restrita. Acta Scientarium Animal Sciences 28:331-337.

Rocha, R. R. C.; Costa, A. P. R.; Azevedo, D. M. M. R.; Nascimento, H. T. S.; Cardoso, F. S.; Muratori, M. C. S. and Lopes, J. B. 2009. Adaptabilidade climática de caprinos Saanen e Azul no MeioNorte do Brasil. Arquivo Brasileiro de Medicina Veterinária e Zootecnia 61:1165-1172.

Sanon, H. O.; Kabore-Zoungrana, C. and Ledin, I. 2007. Behaviour of goats, sheep and cattle and their selection of browse species on natural pasture in a Sahelian area. Small Ruminant Research 67:64-74.

Santos, S. B.; Faccini, J. L. H. and Santos, A. C. G. 2006. Variação estacional de Bovicola caprae parasitando caprinos no Estado da Paraíba. Pesquisa Veterinária Brasileira 26:249-253.

Silva, I. J. O.; Barbosa Filho, J. A. D.; Silva, M. A. N. and Piedade, S. M. S. 2006. Influência do sistema de criação nos parâmetros comportamentais de duas linhagens de poedeiras submetidas a duas condições ambientais. Revista Brasileira de Zootecnia 35:1439-1446.

Souza, S. R. L.; Nääs, I. A. and Moura, D. J. 2011. Análise de imagens para a caracterização das atividades de vacas leiteiras dentro do galpão de confinamento. Engenharia Agrícola 31:1036-1043.

Werry, D. M. and Fraser, D. 2002. Social and reproductive behaviour. p.73-84. In: The ethology of domestic animals: an introductory text. CAB International, Canadá.

Zanine, A. M.; Vieira, B. R.; Ferreira, D. J.; Vieira, A. J. M.; Lana, R. P. and Cecon, P. R. 2008. Comportamento ingestivo de diversas categorias de bovinos da raça Girolanda, em pasto de Brachiaria brizantha cv. Marandu. Arquivo de Ciências Veterinárias e Zoologia da Unipar 11:35-40. 